\title{
Cooperation Between Albania and Kosovo and Its Impact in Strengthening the Rule of Law Against Transnational Organized Crime, 2008-2015
}

\author{
Bajram Ibraj
}

\author{
PhD Candidat
}

\begin{abstract}
Transnational organized criminal activities and local activities have affected both countries, Albania and Kosovo. Meanwhile, transnational crime with transnational and local base Albania-Kosovo, is of interest and influence, therefore, it is suggested that the cooperation between the Republic of Albania and the Republic of Kosovo in this regard be serving in law enforcement institutions in Albania and within law enforcement institutions in Kosovo. Transnational organized crime, terrorism, corruption and money laundering are global security threats and local, regional and international sources of crises. Organized crime knows no nationality, no countries, borders, homeland, race, ethnicity, religion and religious beliefs. That is why it is required cooperation in the fight against transnational organized crime and transnational organized crime to be implemented permanently with the main goal of the strategy implementation, action plans, joint operations between the two countries, Albania and Kosovo. Important role in this association play their respective law enforcement institutions such as the police of the two countries, prosecutions, courts and other institutions. While international cooperation is realized with major international organizations like the UN, the EU, Interpol, Europol, SECI center etc. During the years 2002-2015 between the governments, ministries of internal and Police of the Republic of Albania and the Republic of Kosovo hav signed several agreements, memoranda of understanding and common protocols. Interstate and transnational cooperation through the tabulation and graphs presented and seek to build strategies, institutions, measures, operations and joint actions with preventive, managers and common problem solvers of security and the fight against transnational organized crime. Consolidation of security in Albania and Kosovo, is closely associated with the construction, consolidation and functioning of the rule of law, and the rule of law, reaching freedom and respect for fundamental human rights. Albania-Kosovo cooperation significantly affects the strengthening of the rule of law against transnational organized crime. This cooperation is a necessary precondition for the prevention of conflicts and internal, external and regional crises, in order to achieve security and human rights and freedom.
\end{abstract}

Keywords: International cooperation, transnational organized crime, lay, security, ekstradimi.

\section{Introduction}

"National" or internal organized crime, ${ }^{1 "}$ "nternational" organized crime,,2 "Transnational" organized crime ${ }^{3}$ or "international", "global" organized crime or "multination"4 in today's world is turned into a global "phenomenon". Globalization-trend of the NWO deals with numerous technological developments, but not only, and has had a positive impact on economic development and global technology. On the other hand, transnational organized crime, is the "dark side" of globalization ${ }^{5}$ because globalization which is considered " a global village" has brought it nearer also the

\footnotetext{
1"National"organized crime or internal called when it occurs within the national borders of a country

2 "Transnational" organized crime is when a criminal organization extends its country and also operates in other countries

3 "Transnational" organized crime is a criminal organization that operates also in other countries cooperating with criminal organizations in these countries

4 "Global" organized crime or multinational called criminal organization in the form of enterprises, organizations or criminal enterprises composed of different countries and nations who exercise their criminal activities in countries and nations

5Jennifer L.Hesterman the Terrorist-Criminal Nexus An Alliance of International Drug Cartels, Organized Crime, and Terror Groups CRC Press was suddenly not the "island" it had always seemed
} 
transnational organized crime. Through the transnational organized crime the "bad" world has become a global "village" that is used more by crime and criminals. Therefore, the "global problems respond to local initiatives, but they also require global solutions". ${ }^{1}$

Transnational organized crime has created social problems of society, but in terms of transnational and multinational organized crime, has created major concerns, has created murder, death, violence, serious crimes and high social risk, it has created numerous victims and "subdued" social strata, classes, groups, individuals up areas, districts, villages, neighborhoods, institutions, governments of individual countries that are part of organized crime addiction. Organized crime knows no nationality, countries, borders, homeland, race, ethnicity, religion and religion beliefs .Therefore, "we must not forget that criminal organizations have no border problems and act with complete assurance throughout the world". ${ }^{2}$ In this regard "messy play of market and anarchic tendencies have led to pillage capitalism, as Soros has called it, it led to this kind of anarchy in creation of private capital, which has brought real usurpation of national, state funds and markets by certain groups ..."3 But "these arrangements might be called predatory capitalism because the most effective way to raise private capital from a zero starting point was acquiring state assets". ${ }^{4}$ To prevent these actions Giovanni Falcone says: "... of course it is a practicable way of multilateral conventions, but many countries give their consent for them with great caution, making purely nominal." ${ }^{5}$ Therefore, not recognizing, not valuating and neglecting the aspects of international cooperation to fight the "phenomenon" of transnational organized crime, not only impacts negatively on countries, international organizations, on the other hand, affects positively and become a very important condition and advantageous for groups, organizations and enterprises of criminal enterprises to achieve their goals.

\section{Interstate cooperation in the fight against transnational organized crime and preventing internal crises}

The most disturbing occurrences for the new world order are the new forms of crises which are proven by international conflicting figures such as organized crime, international terrorism and money laundering, which does not recognize and does not have borders, do not have home, they do not carry color ideological, religious, racial and cultural. "...terrorism and organized crime have for financial institution the black money". 6 They are rooted to the axis of evil and serve him. "... in the time after the Cold War is seen growing a collision between opening tendencies of globalization trends and closing tendencies of nationalism"..7 Giovanni Falcone, referring to some analysts says, "are very dangerous, with incalculable damage and paradoxically, some attempts repeated, seeking to establish that organized crime does not exist as a joint criminal enterprise", and that such concepts, "sometimes expressed by politicians, but also a lawyer, appear too naïve.". ${ }^{8}$ Transnational organized crime and criminals "stay one step ahead" "stay one step ahead," of law enforcement.

Organized crime, terrorism and money laundering, etc., are threats to global security and local sources of crises, regional and international. The Western Balkans has an important position, but also complicated geostrategic." ...The Western Balkans is facing the need to take a number of measures. Our region represents a field with past crises, conflicts and wars. Let us remember that Bosnia, Serbia, Kosovo, Croatia became involved in the war, while Albania and Macedonia took serious crisis in that destabilizing environment, great potential of weapons are cheap in the hands of the region's population. On the other hand, in some areas have been identified participants in local wars of some volunteers with criminal and terrorist precedents or connection with the origin of terrorism sponsoring countries "..9

How must we fight organized crime, has been designated by judge Giovanni Falcone ${ }^{10}$ who said: "The reality criminal mafia is too heavy, but should not be forgotten that they are humans like us, even those who belong to organized crime, who like all human things, can be overcome and won ... but ... it is required commitment of police forces and magistrates, coordinated

\footnotetext{
${ }^{1}$ Anthony Giddens:"The third Way", English edition 1988, page 153 (obtained from Prof. Përparim Kabo "Authoritarianism in Transition. Albanian anthropology through globalism ", Tirana, 2006, page 382)

2Zamir Poda "Organized Crime", Tirana 1998, page 26

3Prof. Përparim Kabo "Authoritarianism in Transition. Albanian anthropology through globalism ", Tirana, 2006, page 385

${ }^{4}$ George Soros: "Crisis of Global Capitalism ", English edition, page 154

5Zamir Poda "Organized crime", Tirana 1998, page 29

${ }^{6}$ Prof. Dr. Lisen Bashkurti "International crises" Tirana 2008

"George Soros: " Crise of global capitalism", Albanian edition, page 19

¿Zamir Poda "Organized crime", Tirana 1998, page 89

9Prof. Dr. Lisen Bashkurti “International crises", Tirana 2008, page 11

10Italian judicial martyr
} 
with the work for the gradual abolition of availability of the population to tolerate the occurrence of such phenomena, which often encountered, it can provide an important contribution to weaken the potency that criminal organizations possess. ${ }^{1}$ While, on the strengthening of cooperation against transnational crime, Godson, Roy and Williams Phil "Strengthering Cooperation against Transnational Crime, Survival" states that "Transnational organized crime is a critical challenge for democratic governance and the transition and modernization processes in many parts of the world. In response to this challenge it requires a comprehensive strategy that combines law enforcement and respond to regulatory requirements, such as analysis of enhanced intelligence and intelligence sharing, building state and inter-state cooperation, approaches non-regulatory, such as expansion strategy in civil society and the private sector. The latter would involve changing cultural attitudes against organized crime and corruption "..2

First of all, good cooperation, giving them the talents available within the law enforcement institutions in Albania and in Kosovo, as well as with other countries and relevant international institutions.

Table 1 reflects the international operations by the State Police Albania, 2008-2012

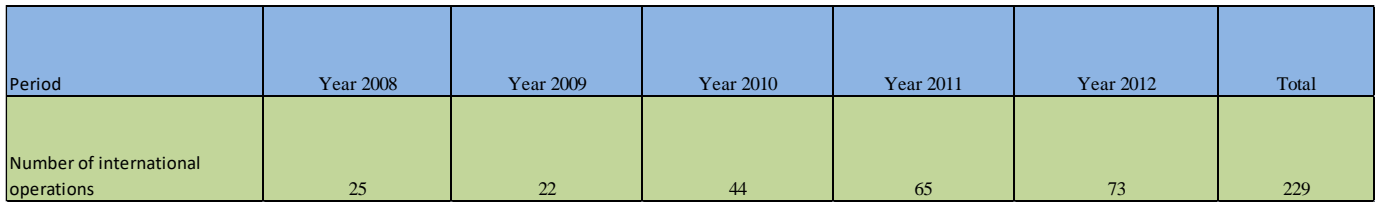

Source: annual activity reports of the Kosovo Police for the years 2008-2012. Processing Copyright (2016)

In the table according to State Police Albania, presented the number of international operations for the period 2008-2012 and shows that in total have developed a total of 229 international operations. Developed international operations in 2011 and 2012 constitute $60.26 \%$ of international operations. Meanwhile, in 2008 and 2009 were developed international operations total $47 \%$ or $20.52 \%$. During 2015 were developed "over 16 joint operations (with expansion in some countries), 70 joint police operations with international partners". ${ }^{3}$ While in Kosovo by the Kosovo Police, Kosovo Customs and the Financial Intelligence Unit for the period 2010-20134 were conducted 295 joint operations, prevention of organized criminal activities in the areas of economic crimes, narcotics and organized crime, with a view to confiscation of monetary values during their trans boundary movements.

International cooperation is an extremely important and complex matter. In the first place, it has to do with awareness of the destabilizing capacity of transnational crime, and secondly, the ability to give impetus to the processes of legislative harmonization and consistent national policy. Therefore, we need that the fight against organized crime should be made as work on major international organizations like for example the UN, the EU, Interpol, Europol, SECI center etc. On the other hand, we should not forget that are regulated enterprises, organizations, Mafia and criminal groups in the world which seek to extend their activities across the country, the region and the world. Therefore, it beggars belief to know first and we know that weak states or failed states as countries of the third world, or countries that have fragile institutions, policies volatile, totalitarian states, democracy underdeveloped, weak economies, poverty unemployment, lack of investment, managing the state and politicians, high state dictators, totalitarian, corrupt, we come to see more clearly and accurately from the outset, starting with the right to work for the formulation of policies, strategies, programs and action plans of institutions to fight to the maximum the transnational organized crime.

${ }^{1}$ lbid, page 18

${ }^{2}$ Godson, Roy and Williams Phil "Strengthering Cooperation agains Transnational Crime, Survival,Vol.40, No.3, Autumn 1998http://www.tandfonline.com/doi/abs/10.1093/survival/40.3.66\#.VKChrsAEA

3lbid

Web: www.punetebrendshme.gov.al

${ }^{4}$ Assessment report on compliance with international standards in the field of Combating Money Laundering and Combating the Financing of Terrorism (LPP / LFT), 2 December 2014, published by the Council of Europe, F-67075 Strasbourg Cedex. The project against Economic Crime in Kosovo (PECK) www.coe.int/peck 


\section{Interstate cooperation between Albania and Kosovo and the region for preventing and combating transnational organized crime, 2008-2015}

Interstate cooperation at the bilateral level between Albania and Kosovo,2008-2015, takes a strategic importance and is the kingmaker in the framework of cooperation and coordination of state structures, the law enforcement agencies and the institutional and practical level of this cooperation will depend regional cooperation and international cooperation with countries and relevant international organizations.

Albania and Kosovo have their similarities and differences, and it is difficult to make a comparative genuine analysis , because the relevant legislation and forms of criminality and the state of the stage of relevant state institutions and criminal justice are in various stages of training, development and their success. However, since we really are two countries, but we are a nation, we have respective obligations and no matter the not so small difficulties for obtaining relevant data, as well as their comparisons. But this is the first attempt of this kind and as the first experience, the inaccuracies are inevitable or the ambiguities but we think that it will certainly be a positive experience in this regard.

Table No.2 event reflects the activity of organized crime, organized crime Albania, Kosovo, region and transnational organized crime locally based and transnational Albania-Kosovo.

\begin{tabular}{|c|c|c|c|c|c|c|}
\hline & Criminality in Albania & Criminality in Kosovo & $\begin{array}{l}\text { Transnational crime } \\
\text { Albania-Kosovo }\end{array}$ & $\begin{array}{l}\text { Transnational crime } \\
\text { transnational based } \\
\text { Albania-Kosovo }\end{array}$ & $\begin{array}{l}\text { Transnational crime local } \\
\text { based on the Albania- } \\
\text { Kosovo }\end{array}$ & Crime in the Region \\
\hline Activity & $\%$ & $\%$ & $\%$ & $\%$ & $\%$ & $\%$ \\
\hline Drug trafficking & $29.10 \%$ & $19.00 \%$ & $40.80 \%$ & $36.90 \%$ & $36.00 \%$ & $27.00 \%$ \\
\hline Corruption & $27.60 \%$ & $33.00 \%$ & $13.60 \%$ & $4.90 \%$ & $6.70 \%$ & $8.80 \%$ \\
\hline Money Laundering & $14.90 \%$ & $12.00 \%$ & $11.70 \%$ & $10.70 \%$ & $15.70 \%$ & $13.90 \%$ \\
\hline Contract killing & $7.50 \%$ & $2.00 \%$ & $3.90 \%$ & $6.80 \%$ & $4.50 \%$ & $1.50 \%$ \\
\hline Human trafficking & $6.70 \%$ & $7.00 \%$ & $9.70 \%$ & $18.40 \%$ & $19.10 \%$ & $19.70 \%$ \\
\hline Putting fines & $3.70 \%$ & $2.00 \%$ & $0.00 \%$ & $0.00 \%$ & $1.10 \%$ & $0.70 \%$ \\
\hline Smuggling of migrants & $3.00 \%$ & $8.00 \%$ & $7.80 \%$ & $4.90 \%$ & $3.40 \%$ & $6.60 \%$ \\
\hline Weapons trafficking & $3.00 \%$ & $9.00 \%$ & $5.80 \%$ & $12.60 \%$ & $6.70 \%$ & $8.80 \%$ \\
\hline Terrorism & $3.00 \%$ & $6.00 \%$ & $5.80 \%$ & $4.90 \%$ & $5.60 \%$ & $10.90 \%$ \\
\hline Cybernetic Organized Crime & $1.50 \%$ & $2.00 \%$ & $1.00 \%$ & $0.00 \%$ & $1.10 \%$ & $2.20 \%$ \\
\hline
\end{tabular}

Source: Responses to the questionnaire "Democratic Institutions and Transnational Organized Crime Albania, Kosovo, 2008-2015". Processing Copyright (2016)

According to this table it reflects 14 events or forms of organized crime and organized criminology in Albania, Kosovo, transnational crime, transnational crime with transnational base and transnational basis Albania-Kosovo-based local and criminality in the region, on the basis of which may build better cooperation in this direction for more efficient fight against transnational organized crime. Comparing six aspects such as: transnational crime Albania, Kosovo, transnational crime with transnational base Albania-Kosovo, transnational crime with local base Albania and Kosovo, and regional criminality results in these directions, drug trafficking is ranked on the first level, trafficking in human beings is ranked at level second, and corruption ranked third level. Meanwhile, locally based transnational criminality Albania-Kosovo ranks at lower levels than transnational crime Albania, Kosovo and transnational crime based transnational Albania-Kosovo. By the analys of the above comparisons, the most developed organized crime in Albania and in Kosovo results to be the organized crime based transnational Albania-Kosovo and less developed results the local based Albania-Kosovo.

While crime in the region is at a higher level compared to organized crime in Albania and Kosovo in organized criminal activities of human trafficking, terrorism, arms trafficking, smuggling of migrants and organized cyber crime. Meanwhile, 
drug traffic is almost at the same level with drug trafficking in Albania and level two times higher compared with drug trafficking in Kosovo.

During the years 2002-2015 between the governments, the internal ministries and Police of the Republic of Albania and the Republic of Kosovo, there have been signed 21 agreements, memoranda of understanding and common protocols. The governments of Albania and Kosovo have signed 6 agreements, 1 memorandum and two common protocols. Interior Ministries have signed 2 agreements, 4 memoranda of cooperation and 8 common protocols.Meanwhile the police of the two countries has signed 1 agreement 1, 1 cooperation memorandum and 1 common protocol. Pursuant to the agreements, memoranda of understanding and the common protocols are conducted parallel investigations, through the exchange of information and operational activities for mutual assistance. For mutual recognition and execution penal court decisions it is signed an agreement with Austria. While in connection with the arrangements for transfer of sentenced people-it is a party dënuar- is a party, Albania, Switzerland, Belgium, Turkey, Czech Republic, Macedonia, as well as agreements signed (2013) agreements on extradition and judicial cooperation related to criminal matters -with Italy.

Table No.3 reflects police cooperation agreements between Kosovo and other States, 2008-2015.

\begin{tabular}{|c|c|c|c|c|c|}
\hline Years & $\begin{array}{c}\text { Police cooperation } \\
\text { agreements }\end{array}$ & $\begin{array}{c}\text { Cooperation } \\
\text { agreements in the } \\
\text { operative field }\end{array}$ & $\begin{array}{c}\text { Cooperation } \\
\text { agreements with } \\
\text { EULEX }\end{array}$ & $\begin{array}{c}\text { Cooperation } \\
\text { agreements in the } \\
\text { field of border }\end{array}$ & Total \\
\hline 2008 & 1 & 0 & 2 & 0 & 3 \\
\hline 2009 & 3 & 0 & 3 & 1 & 7 \\
\hline 2010 & 3 & 1 & 0 & 1 & 5 \\
\hline 2011 & 0 & 1 & 0 & 5 & 6 \\
\hline 2012 & 4 & 1 & 2 & 2 & 7 \\
\hline 2013 & 2 & 1 & 1 & 6 & 13 \\
\hline 2014 & 3 & 1 & 0 & 2 & 11 \\
\hline 2015 & 7 & 1 & 2 & & 2 \\
\hline
\end{tabular}

Source: Annual Statistics of the General Directorate of Prisons at the Ministry of Justice in Tirana, 2010, 2011, 2012, 2013, 2014, 2015. Processing Copyright (2016)

According to this table, the agreements of police cooperation between Kosovo and other countries for the period 20082015 it results a total of 62 results that are agreements by which, an agreement of police cooperation, 23 or $37.09 \%$, cooperation agreement in the operative field, 6 or $9.67 \%$, agreement of cooperation with EULEX, 8 or $12.90 \%$ and cooperation agreement in the field of border, 25 or $40.32 \%$. By comparing the joining number of agreements signed during the years 2008-2015 it shows that in 2008-2012, there are signed 28 agreements or $45.16 \%$, whereas in the years 2013 , 2014 and 2015 a total of 34 agreements were signed or $54.83 \%$.

These agreements by the Republic of Kosovo are connected to 18 countries, namely: Austria, Bulgaria, Great Britain, France, Finland, Germany, Hungary, Croatia, Lithuania, Macedonia, Montenegro, Sweden, Serbia, Slovenia, Albania, USA, Turkey and Switzerland. While the International Organizations Frontex have signed multinational Agreement (Kosovo, Albania, Macedonia, Montenegro, Bosnia and Herzegovina, Serbia).The Interior Ministry with the Customs, have signed a total of 12 cooperation agreements with :12 countries, while 10 countries are preparing draft agreements and are in the process of study and negotiation. While the Interior Ministry with the Financial Intelligence Unit have signed a total of 13 cooperation agreements with 11 countries, while 9 countries have prepared agreement. In order to prevent and combat the transnational organized criminal activities and local activities that have affected both our countries, Albania and Kosovo, it is requested intensification of cooperation between the Republic of Albania and Republic of Kosovo.And in Kosovo within law enforcement institutions, and then to identify projects of cooperation between Kosovo and Albania, prepared, adopted and implemented by both sides correctly. To have good cooperation between the Republic of Albania and the Republic of Kosovo as a whole in all areas, as well as in the fight against trasnational and organized criminal activities and local criminal activies that have affected both countries, requires first of all good cooperation to exist within law enforcement institutions in Albania ${ }^{1}$ and within law enforcement institutions in Kosove, and then it needs to be identified the projects of cooperation

${ }^{1}$ The annual analysis of the State Police in 2015 
between Kosovo-Albania, they need to be prepared, to be adopted, and to be applied correctly by both parties. Ernst Florian Winter says: "Cooperation between Kosovo and Albania should be released from the complexes, but also from the pathetic of great words. This requires a shift in the identification of projects of mutual interest. Both governments have the opportunity to do more about infrastructure projects (roads, energy, ports), education and health, in these three segments there are many problems The two onlz countries perhaps in Europe, have not yet been able to provide electricity, water, education of high standards and dignified recovery for citizens. Joint projects in these areas should be well managed throughout their cycle, so to realism. Governments should also encourage and facilitate private initiative, businesses, associations and civil society to promote cooperation projects". 1 Joint meetings of two Albanian governments in Kosovo and Albania, have made possible the signing of several agreements, but in addition it is also done good work, their "publicity" is greater than concrete work implemented by relevant structures and institutions in joint ground operations.

In connection with international cooperation, the Ministry of Justice for the period 2010-2013, received a total of 10.274 new requests for assistance, of which; 7.488 requests for service of documents, 489 requests for legal assistance of a different nature; 1,169 requests for custom paper, 512 requests for verification of documents; 57 requests for extradition; 114 requests for transfer of judicial procedures; 178 requests for execution of court decisions; 43 requests on international child abductions; 43 requests for transfer of sentenced persons; 13 claims of war crimes; 193 requests for issuance of international research paper. ${ }^{2}$

Table No. 4, shows the number of prisoners from Kosovo citizens extradited from Albania, 2008-2015.

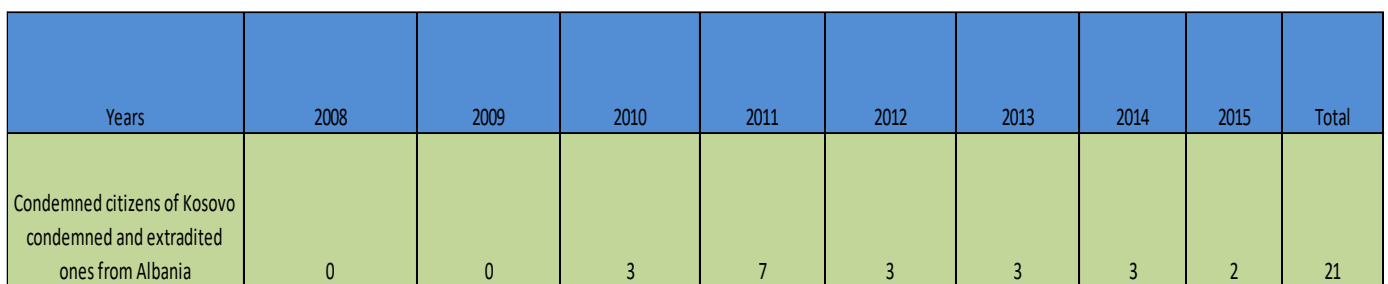

Source: Annual Statistics of the General Directorate of Prisons at the Ministry of Justice in Tirana, 2010, 2011, 2012, 2013, 2014, 2015. Processing Copyright (2016)

On the basis of the annual statistics of the General Directorate of Prisons at the Ministry of Justice in Tirana, for the years 2008-2015, it shows that a total of 21 sentenced citizens from Kosovo and were extradited from Albania.For more information refer to Table No.4 which represents the number of prisoners from Kosovo citizens extradited from Albania, 2008-2015. ${ }^{3}$

Table No.5 reflects the strengthening of the rule of law (Albania-Kosovo) in the fight against transnational organized criminal activities, 2008-2015.

\begin{tabular}{|l|l|}
\hline & $\%$ of answers \\
\hline Suggestion & $7 \%$ \\
\hline Lays & $14 \%$ \\
\hline Law enforcement agencies & $44 \%$ \\
\hline Media & $10 \%$ \\
\hline Education & $14 \%$ \\
\hline Civil society & $12 \%$ \\
\hline Total & $100 \%$ \\
\hline
\end{tabular}

${ }^{1}$ Ernst Florian "Some observations on the social problems of Kosovo", page 113

2 The annual work report of the Ministry of Justice Kosovo, 2010,2011,2012,2013

3 lbid 
Source: Responses to the questionnaire "Democratic Institutions and Transnational Organized Crime Albania, Kosovo, 2008-2015". Processing Copyright (2016)

According to this table, respondents under question $9{ }^{1}$ of the questionnaire, ${ }^{2}$ have been answered ${ }^{3}$ by their response they suggest that $44 \%$ of the agencies of law enforcement impact on strengthening the rule of law Albania and Kosovo in the fight against criminal activities of organized transnational, and suggest the extent $14 \%$ law, $14 \%$ education, $12 \%$ civil society, $10 \%$ and $7 \%$ Constitution. So law enforcement agencies have the main weight to strengthen the rule of law AlbaniaKosovo.

\section{Conclusions}

Cooperation between Albania and Kosovo and its impact in strengthening the rule of law against transnational organized crime and international cooperation is an extremely important matter and complex. Only an intergovernmental and interagency cooperation in the fight against transnational organized crime and terrorism is a prerequisite for the prevention of conflicts and crises, domestic and foreign, regional and international, and especially the provision of freedoms and human rights.

Interstate cooperation and transnational through tabulation and graphs presented in this paper seek to build strategies, institutions, measures, operations and joint actions with preventive character, managers and common security problem solvers and the fight against transnational organized crime. Consolidation of security in Albania and in Kosovo have as common foundation the prerequisite consolidation and functioning of the rule of law, rule of law, consolidation of the institutions of justice and respect for freedoms and basic human rights, at the local level, interstate, transnational and beyond.

\section{Bibliography}

[1] Anthony Giddens:" "The Third Way", English edition 1988

[2] Dr. Zamir Poda "Organized Crime", Tirana 1998

[3] Ernst Florian Winter "Some observations on the social problems of Kosovo"

[4] Evaluation report on compliance with international standards in the field of combating money laundering and combating the financing of terrorism (LPP / LFT), 2 December 2014, published by the Council of Europe, F-67075 Strasbourg Cedex. Project Against Economic Crime in Kosovo (PECK)

[5] George Soros :"Crisis of Global Capitalism", Albanian edition

[6] George Soros: "Crisis of Global Capitalism", Albanian edition

[7] Godson, Roy and Williams Phil "Strengthering Cooperation agains Transnational Crime, Survival,Vol.40, No.3, Autumn 1998

[8] http://www.tandfonline.com/doi/abs/10.1093/survival/40.3.66\#.VKChrsAEA

[9] Law Nr.9496, 20.3.2006 On the ratification of the "Agreement between the Council of Ministers in the Republic of Albania and the temporary Mission of the United Nations Administration in Kosovo (UNMIK) for the transfer of sentenced persons"

[10] Prof. Dr. Lisen Bashkurti "International crises" Tirana 2008

[11] Prof. Përparim Kabo "Authoritarianism in Transition. Albanian anthropology through globalism ", Tirana, 2006

[12] Questionnaire "Democratic Institutions and Transnational Organized Crime, Albania, Kosovo, 2008-2015"

[13] Responses were received from 55 dignitaries, experts in Albania, Kosovo and international experts interviewed by author

[14] The annual analysis of the State Police in 2015

[15] Web: www.punetebrendshme.gov.al

[16] www.coe.int/peck

${ }^{1}$ Question 9. What do you recommend to strengthen the rule of law (Albania-Kosovo) in the fight against transnational organized criminal activities and transnational?

${ }^{2}$ Questionnaire "Democratic Institutions and Transnational Organized Crime, Albania, Kosovo, 2008-2015"

3 Responses were received from 55 dignitaries, experts in Albania, Kosovo and international experts interviewed by author 